\title{
Surplus Books Available from Army and Navy Instructional Programs
}

Part of a summary prepared by Jesse Hauk Shera from returns from a questionnaire sent from A.L.A. Headquarters for the A.C.R.L. Committee on Wartime Activities, Feb. 24, 1945.

Of the II 5 questionnaires sent out from A.L.A. Headquarters, returns were received from 75 libraries. Of the number which answered, 31, or almost one-third, replied "no" to the first question asking whether they had or would have books or periodicals to be offered for sale.

Of the remainder, 16 replied to the second question that they had no knowledge of any plans to dispose of surplus library materials when the training courses sponsored by the armed services were liquidated and Io others said that their stocks had reverted or would revert to the military or naval authorities establishing the projects. Of this last group, two libraries indicated that the books had first been offered to them for their collections but in neither case were they interested. In 15 institutions all or a portion of the books were acquired by the university, and of these, 7 returned surpluses to the armed services, a similar number sold at least a part of theirs through the college bookstore, and in 9 instances the library purchased all or a part of the books.

In answer to question three, concerning the character of the volumes, there was universal agreement that they were almost entirely texts; 22 libraries stated that they were largely in engineering, I I showed a great proportion of titles used in the study of foreign languages, and the remainder indicated that the books represented a wide variety of texts in history, government, science, geography, and "Western civilization." As one might expect, most of the collections were composed of relatively few titles duplicated in large quantities.

There was general agreement, too, in the belief that by and large these books were unsuitable for libraries, and 13 said so in so many words. However, 16 expressed the opinion that they might contain some titles useful to the small college, 12 thought that possibly the larger universities might find a few of the books serviceable for reserve purposes, 7 believed that public libraries might find them useful, but only 4 considered any of the materials appropriate to the needs of libraries in rural communities. Two librarians suggested selling the books to dealers.

By way of summary it may be concluded that the surplus books remaining after the discontinuance of the army and navy programs have little value for any library and that the disposal of these residual titles offers no opportunity for a coordinated interlibrary program. The relatively low importance of the books, taken in conjunction with the governmental requirement of lot bidding, which compels the purchaser to take all or none, suggests that the best method of handling this problem is for each institution to work it out as best it can with reference to its own particular situation. 